\title{
THE EFFECTIVENESS OF COOPERATIVE LANGUAGE LEARNING IN TEACHING VOCABULARY
}

\author{
Wahyu Trimastuti \\ Email:trimastutiw@yahoo.com \\ University of Pembangunan Nasional Veteran, Surabaya
}

\begin{abstract}
This study aims to determine whether the Cooperative Language Teaching and Learning method is more effective than the traditional learning to teach vocabulary. This is an experimental quantitative research. The population for this study is freshmen majoring in management. The use of Cooperative Language Teaching and Learning method through engineering teams-games-tournament (TGT) in the English vocabulary learning is considered to be effective, creative, and fun to increase the students' motivation to learn and to improve their vocabulary mastery. The findings showed that the Cooperative Language Teaching and Learning is an effective method to teach vocabulary. It is, thus, recommended that (1) the Cooperative Language Learning and Teaching improve the students' ability to remember vocabulary, (2) students are expected to be more active in the learning process in order to improve the ability to solve the problem of vocabulary (3) the results of this study can be used as an initial step to hold further research.
\end{abstract}

Keywords: cooperative language learning, TGT, vocabulary

\section{INTRODUCTION}

Teaching English has been done in formal and non formal education sectors. In formal education, it has been done from primary school until university level. Based on curriculum of university, particularly University of Pembangunan Nasional 'Veteran' Jawa Timur, English is learnt by students at first and second semester. English is learnt at first semester called general english, while english is learnt at second semester called english spesific purpose. The objective of English instruction at university is to develop the communication ability in English in the form of spoken and written. The ability to communicate consists of listening, speaking, reading, and writing. These are related to each other. These aspects will be expected to be able to prepare the students to continue to the next stage of education 
or to get a job, in which the graduation should have the requirement in English competence. For anticipating that issue in the globalization era, students should have prepared with the competence related to their department which is supported by their competence in English, both receptive skills (reading and listening) and productive skills (writing and speaking).

In learning english language, vocabulary plays an important role. It is one important element of learning English that will influence the four English skills: speaking, listening, reading, and writing. In order to communicate well in english language, students should acquire an adequate number of words and should know how to use them accurately. Carter and Mc Carthy (1995, p. 12) describe that in the early stages of language learning, words are conventionally learned in lists of paired words or 'paired associates'. The list contains a word from the target language, with synonym in that target language, or a translation in the mother tongue, and these can be accompanied by a picture, or some means of graphics or other mnemonic representation. Chomsky (1957, p. 116) states that words and morphemes are the smallest meaningful units in language. For the most part, however, people communicate in phrases and sentences, which also have meaning. The meaning of a phrase or a sentence depends on both the meaning of its words and how these words are structurally combined. From the definition above, it can be conclude that word is the smallest units in language. Every word is meaningful, by the meaningful of a word, people produce words to express their idea and thought in their daily communication.

Vocabulary is a series of words in foreign language used to express menaing in form of symbols of groups of letter, either a physical object or an idea. It can be also formed from a single or more than one word which can be constructed as an ability to combine skill or knowledge of words that are used to express meaning. In english teaching, vocabulary plays an important role crucial. It is central of language teaching and learning. By mastering vocabulary students easier to make communication with others fluently. Cross (1995, p. 14) states that a good store of words is crucial for understanding and 
communication. A strong vocabulary can be a valuable asset, both in college and later in our career.

The students will get difficulties in mastering English without knowing a lot of vocabulary. Thus, vocabulary should be the first priority in English language teaching and learning. As a lecturer of English language in UPN 'veteran' Jawa Timur, the writer finds that students have problem related to their vocabulary. Many students find it difficult to get the meaning of the text when they join the teaching learning process. They are passive in joining the english class. They have low vocabularies that influence their interest in english class. Therefore, their english test result is not good. It is supposed that the method used is inappropriate. The method used is supposed to be less effective to improve student's vocabulary. The method does not give much opportunity to the students to be active. To respond to this situation, the writer tries to improve students vocabulary by using Cooperative Language Learning, particularly teams-games-tournament (TGT) in english teaching learning process.

There are some problems that can be identified from the situation, they are: (1) why students tend to have low vocabulary, (2) why students look passive in teaching learning process, (3) what factors cause students' low vocabulary achievement, (4) does the method of teaching used by teachers influence students' vocabulary, and (5) does teams-games-tournament (TGT) method give an optimal learning outcome in teaching vocabulary.

The study is expected to be able to reveal the students' competencies and potential conditions in mastering vocabulary. They find meaningful strategy to overcome their problems and improve their vocabulary mastery.

\section{VOCABULARY}

Hatch and Brown (1995, p. 1) state that vocabulary is a list or set of words for a particular language or a list or set of words that individual speakers of a language might use. McWhorter (1989, p. 311) states that vocabulary means the ability to recognize individual words and to associate meaning with the particular combination of letters that form a word. It means that vocabulary is written or spoken 
unit of language as symbol of idea. In other word, vocabulary is the competence or skill in recognizing words and its meaning.

Vocabulary is an important aspect in english teaching learnimg process. The vocabulary mastery can't be done spontaneously but step by step. Keraf (1989, p. 65-66) defines the step in processing vocabulary mastery form children until adult. First, children period, children are able to define concept vocabulary to say their concrete idea. Second, adolescent period, the adolescent starts to use the language and makes it more extensive directly in simple communication. Third, adult period, the vocabularies are used more and more intensively because they make more communication each other.

\section{Types of Vocabulary}

According to Kitao (1996), vocabulary knowledge can be divided into three types, they are:

1. Active speaking vocabulary, that is, words that the speaker is able to use in speaking. Due to the spontanaeous nature of the speaking vocabulary, words are often misused. This misuse - though slight and unintentional - may be compensated by facial expressions, tone of voice, or hand gestures.

2. Passive listening vocabulary, which is words that the listener recognize but cannot necessarily produce when speaking. This vocabulary is aided in size by context and tone of voice.

3. Passive reading vocabulary, which refers to words that a reader recognize but would not necessarily be able to produce.

\section{The Factors of Vocabulary}

Thornbury (2002, p. 27) declares some factors why learning vocabulary is rather difficult for second language learner. They are (1) pronounciation; (2) spelling; (3) length and complexity; and (4) grammar, meaning, range, connotation and idiomaticity.

According to Cameron (2001. p. 85) which in turn draws on work by Richard differ some aspects of word knowledge. They are summarized in the following table: 
Table 1 Aspects of Word Knowledge

\begin{tabular}{|c|c|}
\hline Type of Knowledge & What is involves \\
\hline $\begin{array}{l}\text { Receptive } \\
\text { aural/decoding }\end{array}$ & $\begin{array}{l}\text { To understand it when it is } \\
\text { spoken/writen }\end{array}$ \\
\hline Memory & To recall it when needed \\
\hline Conceptual knowledge & To use it with the correct meaning \\
\hline $\begin{array}{l}\text { Knowledge of spoken form: } \\
\text { phonological knowledge }\end{array}$ & $\begin{array}{l}\text { To hear the word and to pronounce it } \\
\text { acceptably, on its own, and in phrases } \\
\text { and sentences }\end{array}$ \\
\hline Grammatical knowledge & $\begin{array}{l}\text { To use it in a grammatically accurate } \\
\text { way; to know grammatical connections } \\
\text { with other words }\end{array}$ \\
\hline Collocation knowledge & $\begin{array}{l}\text { To know which other words can be used } \\
\text { with it }\end{array}$ \\
\hline Orthographic knowle & To spell it correctly \\
\hline $\begin{array}{l}\text { Pragmatic } \\
\text { knowledge of stile and } \\
\text { register }\end{array}$ & To use it in the right situation \\
\hline Connotation knowledge & $\begin{array}{l}\text { To know its positive and negative } \\
\text { associations, to know its associations } \\
\text { with related words }\end{array}$ \\
\hline Metalinguistics knowledge & $\begin{array}{l}\text { To know explicity about the word, e.g. } \\
\text { its grammatical properties }\end{array}$ \\
\hline
\end{tabular}

\section{Aspects of Vocabulary}

According to Ur in Pavlu (2009: 26), the aspects of vocabulary are as follows:

1. Form: to know the form of a word means to know the pronunciation and spelling of a word. Pronunciation is what a word sounds like and spelling is what it looks like. In teaching learning process, the pronunciation has to accurately presented and learned.

2. Grammar: the grammar of new item will be necessary to be taught if this is not obviously covered by general grammatical rules. An item which may have an unpredictable change of form in certain grammatical contexts may have some idiosyncratic way of connecting with other words in sentences; it is important to 
provide learners with this information at the same time as teachers teach base form.

3. Aspect of Meaning

a. Synonyms: item that means the same, or nearly the same: for example, bright, clever, smart may serve as synonyms of intelligent.

b. Antonyms: items that mean the opposite: rich is an antonym of poor.

c. Hyponyms: items that serve as specific examples of general concepts; dog, lion, mouse are hyponyms of animal.

d. Co-hyponyms or co-ordinates: other items that are the 'same kind of thing'; red, blue, green, and brown are co-ordinates

e. Superordinate: general concepts that 'cover' specific items; animal is the superordinate of $\mathrm{dog}$, lion, mouse.

f. Translation: words or expressions in the learners' mother tongue that are more or less equivalent in menaing to the item being taught.

Based on the explanation above, it can be concluded that vocabulary involves knowing about meaning, using words, pronounciation, and spelling of the word which should be mastered by the students.

\section{COOPERATIVE LANGUAGE LEARNING}

Nunan in Zhang (2010, p. 82) shows the characteristics of Cooperative Language Learning on the table below:

Table 2. Comparison of Cooperative Language Learning and Traditional Language Teaching

\begin{tabular}{|l|l|lr|}
\hline & \multicolumn{1}{|c|}{$\begin{array}{c}\text { Cooperative } \\
\text { Language Learning }\end{array}$} & \multicolumn{1}{|c|}{$\begin{array}{c}\text { Traditional Language } \\
\text { Teaching }\end{array}$} \\
\hline Independence & Positive participator, & None or negative \\
\hline Learner roles & $\begin{array}{l}\text { Active receiver and } \\
\text { autonomous learners } \\
\text { performer }\end{array}$ \\
\hline Teacher roles & $\begin{array}{l}\text { Organizer and counselor } \\
\text { of group work, facilitator } \\
\text { of the communication }\end{array}$ & $\begin{array}{l}\text { The centerof the } \\
\text { lassroom, Controller of } \\
\text { teaching pace and }\end{array}$ \\
\hline
\end{tabular}




\begin{tabular}{|c|c|c|}
\hline & $\begin{array}{l}\text { tasks, intervener to teach } \\
\text { collaborative skills. }\end{array}$ & $\begin{array}{l}\text { direction, judge of } \\
\text { students' right or wrong, } \\
\text { the major source of } \\
\text { assistance, feedback, } \\
\text { reinforcement } \\
\text { support }\end{array}$ \\
\hline Materials & $\begin{array}{l}\text { Materials are arranged } \\
\text { according to purpose of } \\
\text { lesson. Usually one } \\
\text { group shares a complete } \\
\text { set of materials. }\end{array}$ & $\begin{array}{l}\text { Complete set of materials } \\
\text { for each student }\end{array}$ \\
\hline $\begin{array}{l}\text { Types of } \\
\text { activities }\end{array}$ & $\begin{array}{l}\text { Any instructional } \\
\text { activity, mainly group } \\
\text { work to engage learners } \\
\text { in communication, } \\
\text { involving processes like } \\
\text { information sharing, } \\
\text { negotitation of meaning } \\
\text { and interaction. }\end{array}$ & $\begin{array}{l}\text { Knowledge recall and } \\
\text { review, phrasal or } \\
\text { sentence pattern practice, } \\
\text { role play, translation, } \\
\text { listening etc. }\end{array}$ \\
\hline Interaction & $\begin{array}{l}\text { Intense interaction } \\
\text { among students, a few } \\
\text { teacher-student } \\
\text { interaction }\end{array}$ & $\begin{array}{l}\text { Some talking among } \\
\text { students, mainly teacher- } \\
\text { student interaction }\end{array}$ \\
\hline $\begin{array}{l}\text { Room } \\
\text { arrangement }\end{array}$ & $\begin{array}{l}\text { Collaborative small } \\
\text { groups }\end{array}$ & $\begin{array}{l}\text { Separate desks or students } \\
\text { placed in pairs }\end{array}$ \\
\hline $\begin{array}{l}\text { Student } \\
\text { expectations }\end{array}$ & $\begin{array}{l}\text { All members in some } \\
\text { way contribute to succes } \\
\text { of group. The one who } \\
\text { makes progress is the } \\
\text { winner. }\end{array}$ & $\begin{array}{l}\text { Take a major part in } \\
\text { evaluating own progress } \\
\text { and the quality of own } \\
\text { efforts toward learning. } \\
\text { Be a winner or loser }\end{array}$ \\
\hline $\begin{array}{l}\text { Teacher- } \\
\text { student } \\
\text { relationship }\end{array}$ & Cooperating and equal & Superior-inferior or equal \\
\hline
\end{tabular}

\section{The Meaning of Cooperative Language Learning}

Macperson (2000, p. 1) states that Cooperative Learning is part of a group of teaching/learning techniques where students interact with each other to acquire and practice the elements of a subject 
matter and to meet common learning goals. Cooperative learning is a teaching strategy involving children's participation in small group learning activities that promote positive interaction. Cooperative learning is a successfull teaching strategy in which small teams, each with students of different levels of ability, use a variety of learning activities to improve their understanding of a subject.

In other sources, Olsen and Kagan (2001, p. 192) state that Cooperative Learning is group learning activity organized so that learning is dependent on the socially structured exchange of information between learners in groups and is motivated to increase the learning of others. Based on the definitions above, it can be concluded that Cooperative Language Learning is group learning that gives interaction and communication between students and students and teachers, take teachers' role as guider, facilitator, and negotiator, and stress the autonomy and centricity of the students in classroom.

\section{Kinds of Cooperative Language Learning}

According to Slavin (2005, p. 11) there are some kinds of cooperative language learning which are often used, they are:

Students-Teams Achievement Divisions (STAD)

The main point of STAD is for motivating the students in order to support and help each other in understanding the materials that are given by the teacher. They may work together, compare the answers, discuss the differences, and help each other if there is a problem. Each of the members of the team should know the material so that they are able to do the test because finally all students must take individual test. Teams-Games Tournament (TGT)

This method is the same as STAD but it changes quiz with join tournaments, where the students will play academic games with members of other teams to contribute points to their team score. Although Teams-Games Tournaments has many similarities with $\mathrm{STAD}$, it adds enjoyment and happiness which is achieved from the game.

Jigsaw II

This is an adaptation of Elliot Aronson jigsaw in 1978. In this technic, the students work in a team which consists of four students. They are 
assigned chapters, biographies, or other materials. Each member in team is assigned to be the expert on some aspects of the reading assigment. After reading the material, the expert from each team discuss the topics, and then they return to their team to explain the topics. Finally, there will be a quiz that cover all topics.

\section{The Notion of Teams-Games Tournament}

Slavin (2005, p. 13) states that Teams-Games Tournaments is a type of Cooperative language Learning that places the students in groups so they need to work together. Isjoni $(2009$, p. 83) states that Teams-Games Tournament is a type of Cooperative Language Learning that places the students in groups. Each group consists of five until six students who have different ability, gender, and vocabulary mastery. Based on the explanation above, it can be concluded that TeamsGames Tournaments is a teaching method that places the students in groups in order that they can work together as a team.

\section{Teaching Steps of Teams-Games Tournaments}

According to Slavin (2005, p. 170), Teams-Games Tournaments consists of the learning activities as follows:

1. Select a instructional topic and present it to the students (e.g. Hobbies)

2. Develope a list of questions on the topic. Number them. Cut out small pieces of paper and number them so that the total matches the number of questions that you developed for the topic to measure understanding (e.g. if you have 35 questions, create small pieces of paper with number 1-35 on them). Give a set of questions to one student in each group who reads the questions as their corresponding numbers are drawn from the pile.

3. Team Game-place students in heterogeneous groups of 4-5 by ability and have them review material during this "team" phase by selecting a number from the pile. Groups must be equal in size. Give each group a "Letter Identity" (e.g. Group A and each student a Number Identity (e.g. Student 1) Students must answer the question that matches the number they selected from the pile. For example, if a student selects \#22 from the pile and question \#22 is 
"I use racket and shutlecock every morning. What is my hobby?" that student is challenged to answer that question. If he or she cannot come up with an answer, a teammate can "steal" the question. Teams share knowledge during this phase of the lesson. (i.e. teach their teammates)

4. Tournament-place students in new groups made up of individuals from each of the "Team Review" tables (step 2). All "Students Is" go to Table 1 (these might be lower achieving students) while all "Students 2s" (higher achieving) go to Table 2. In the "Game" phase, students are placed in homogeneous groups with students of similar ability and compete against one another. For every question a student answers correctly, he or she earns a point. One person at each "tournament table" must keep scores for every individual at the "Game" table.

5. Students return to their Team Game tables and report their scores. Team scores are compared and the winning team earns a reward

6. Students take an assessment. The scores for each Team (e.g. A,B,C...) are compiled and averaged. Offer "bonus points" for the team that earns the highest average and/or "improvement points" to the team that improves its average the most over previous assessments.

The research was conducted at Language Center of UPN 'Veteran' Jawa Timur located at Jl. Raya Rungkut Madya Gunung Anyar. To achieve the objective of the study, the researcher applied an experimental study. The experimental study is defined as the technique, which attempts to find out cause and effect relationship.

Population is the researcher's interest of the group in which he/she would like the results of the study to be generalized (Gay, 1992, p. 125). It is the individuals who have the quality or characteristics in common from which a researcher may get the data. The population of this research was the first semester students of Management in the 2015-2016 academic year, which consisted of four classes (200 students).

The sample of this research was students from two classes, class $\mathrm{A}$ and class B. She took two classes of four classes, one was for 
experimental class (class A) and the other was for control class (class B). Each consisted of thirty students. Sampling is the process of drawing a sample from the population (Mason and Bramble, 1997, p. 113). In this study, the writer used cluster random sampling to get sample.

This research using Tuckey test. It is applied to know the difference between the two teaching methods and the mean score to know that games-team-tornament is more effective in teaching vocabulary.

$$
\mathrm{t}=\frac{M 1-M 2}{\sqrt{\frac{\sum X_{1}^{2}+\sum X_{2}^{2}}{N(N-1)}}}
$$

Note:

$\mathrm{X}=$ The score of vocabulary test of experimental class which is taught by using games-team-tournament

$\mathrm{Y} \quad=$ The score of vocabulary test of control class which is taught without using games-team-tournament

M1 = The mean score of vocabulary test of experimental class which is taught by using games-team-tournament

M2 = The mean score of vocabulary test of control class which is taught without using games-team-tournament

$\mathrm{X}_{1}=\mathrm{X}-\mathrm{M} 1$

$\mathrm{X}_{2}=\mathrm{Y}-\mathrm{M} 2$

$\mathrm{N} \quad=$ The number of students

$\mathrm{t}=\frac{M 1-M 2}{\sqrt{\frac{\sum X_{1}^{2}+\sum X_{2}^{2}}{N(N-1)}}}$

$\mathrm{t}=\frac{81-86}{\sqrt{\frac{1017+847}{60(60-1)}}}$

$\mathrm{t}=\frac{13}{\sqrt{\frac{1864}{3540}}} \quad \mathrm{t}=\frac{13}{\sqrt{0.526}}$ 


$$
\begin{aligned}
& \mathrm{t}=17.93 \\
& \begin{aligned}
\mathrm{db} & =\mathrm{N}-1 \\
& =60-1=59
\end{aligned}
\end{aligned}
$$

Because $t_{o}$ (17.93) is higher than $t_{t}(1.67)$ at the level of significance $(\alpha)=0.05$ and $t_{o}$ (17.93) is higher than $t_{t}(2.39)$ at the level of significance $(\alpha)=0.01$. The mean score of students who are taught using TGT is 81 and the mean score of students who are taught without using TGT is 68 It can be concluded that using TGT is more effective than for teching vocabulary.

\section{CONCLUSION}

Team-Games-Tournament is an effective method to teach vocabulary. In Team-Games-Tournament, learning process are enjoyable. Students become more active and know each other better since they have to study in group work. The high achieving students can work and share ideas with average and low achieving students. The process of learning using Team-Games-Tournament method helps the students develop their vocabulary skill and be able to explore useful information through many different resources.

\section{REFERENCES}

Carter, Ronlad. 1995. Vocabulary Applied Linguistic Perspective. London: Routledge

Cameron, Lynne. 2001. Teaching Languages o Young Learners. United Kingdom: Cambridge University Press.

Chomsky. 1957. An Introduction to Language. Australia: Hartcourt.

Cross. 1993. Language. New York: Holt Renehardt and Winston.

Gay, L.R. 1992. Educational Reserach. Competencies for Analysis and Application New York: Macmilan Publishing Company.

Gay, L.R. 2005. Educational Reserach. Competencies for Analysis and Application New York: Macmilan Publishing Company.

Hatch, E., \& Brown, C. 1995. Vocabulary, Semantics, and Langugae Education. Cambridge: Cambridge University Press.

Isjoni, 2009. Pembelajaran Kooperatif. Meningkatkan Kecerdasan Komunikasi Antar Peserta Didik. Yogyakarta Pustaka Belajar. 
Keraf, Gorys. 1989. Komposisi. Ende: Nusa Indah.

Kitao, S. Kathleen. 1996. Testing Vocabulary. http: / /www.eslgold.com/vocabulary/testing.html. Retrieved on August $21^{\text {st }}, 2016$

Macpherson, Alice. 2000. Cooperative Learning Group Activities for College Courses. A Guide for Instructors. Michigan Kwantlen Polytechnic University.

Macpherson, Alice. 2003. Cooperative Learning Group Activities for College Courses. A Guide for Instructors. Michigan Kwantlen Polytechnic University.

Marson and Brambel. 1997. How to Design and Evaluate Research in Education. New York: McGraw-Hill INC.

McWhorter, Katheleen T. 1989. College Reading and Study Skills. Glenview Illinois Boston London: Niagara Country Community College.

Olsen and Kagan. 2001. Essential of English Language Teaching. London: Longman.

Pavlu, Ivana. 2009. Testing Vocabulary. New Jersey: Masaryk University Brno.

Slavin, Robert E. 2005. Cooperative Learning. Teori, Riset dan Praktik. Bandung: Penerbit Nusa Media.

Thornbury, Scott. 2002. How to Teach Vocabulary. England: Longman. Zhang. 2010. Cooperative Learning in the Classroom. Va: Curriculum Development. 